\title{
低レイノルズ数流れにおける矩形平板翼の空力特性*1 Aerodynamic Characteristics of Rectangular Flat Plate Wings in Low Reynolds Number Flows
}

\author{
溝口誠*2 - 口裕*2 \\ Makoto Mizoguchi and Yutaka Yamaguchi
}

Key Words : Low Reynolds Number Flow, Low Aspect Ratio Wing, Aerodynamic Characteristics, Rectangular Wing

\begin{abstract}
The effect of aspect ratio $(A R)$ on the aerodynamic characteristics of rectangular wings is investigated. Reynolds numbers considered are $7.6 \times 10^{4}$ and $5.2 \times 10^{4}$. Experimental results are compared with analytical ones obtained from Lamar's method. It is shown that the aspect ratio of wings affects the stall characteristics when $A R \leq 2.0$. The aspect ratio also has an effect on the lift slope if $A R \leq 1.5$. Furthermore, maximum lift coefficients increase when $A R \leq 1.0$. Comparisons show that the variations of aerodynamic characteristics are caused by tip vortices. It is also considered that the position of the center of pressure is varied with the angle of attack because of the effects of the laminar separation bubble and tip vortices on wing surfaces.
\end{abstract}

\section{1. 序論}

MAVや火星探査用無人航空機は, レイノルズ数 $R e$ が $10^{4}$ から $10^{5}$ 程度の低レイノルズ数流れを飛行する。その ため, レイノルズ数の低い流れにおける翼特性の理解は, 機 体の開発や制御にとって大変重要である。また，機体の小 型化や輸送の観点から, 小型無人機にはアスペクト比 $A R$ が小さな翼が用いられることも多い1).

低レイノルズ数流れにおける翼厚比の大きな翼型の空力 性能は, レイノルズ数が $10^{5}$ 程度に低下すると悪化するこ とが知られている ${ }^{2,3)}$.さらにレイノルズ数が $10^{4}$ の領域に なると, 空力特性が非線形になることも報告されている ${ }^{4,5)}$. 一方, 翼厚比の小さな翼の空力特性は, レイノルズ数 $10^{4}$ の領域においても線形的であり, レイノルズ数依存性は比 較的小さいことが示されている6,7). Anyoji ら ${ }^{8)}$ は火星大 気を模擬した風洞を用いて，レイノルズ数 $10^{3}$ から $10^{4}$ の 領域における翼型空力特性を実験的に調べている。この研 究からは, 薄い平板翼の空力特性は低レイノルズ数領域に おいても線形的であるが, 翼面上の層流剥離泡が翼の圧力 分布や空力特性に影響を及ほしていることが示されている.

このような低レイノルズ数流れについて, Pelletier と Mueller ${ }^{9)}$ は, アスペクト比 1.0 から 6.0 の矩形翼空力特 性を半載模型を用いて実験的に調べている. 後にTorres と Mueller ${ }^{10)}$ は研究を進め, レイノルズ数 $10^{5}$ の領域におい てアスペクト比や翼平面形が翼の空力特性に及ぼす影響に ついて詳細な研究を行った. Torresらによると, アスペク

\footnotetext{
*1 C) 2012 日本航空宇宙学会

平成 23 年 10 月 26 日, 第 49 回飛行機シンポジウムにおいて一 部発表. 平成 23 年 8 月 31 日原稿受付

*2 防衛大学校システム工学群航空宇宙工学科
}

ト比が 1.5 以上の場合, 翼平面形の空力特性への影響は小

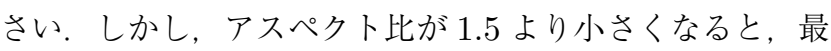
大揚力係数や最大揚力係数が得られる迎え角が高アスペク 卜比の翼と比べて大きくなり，翼平面形による空力特性の 差異も現れることが示されている。 しかし，レイノルズ数 $10^{4}$ の領域においては, アスペクト比が空力特性に及ぼす 影響は明らかにされていない.

そこで本研究ではレイノルズ数 $10^{4}$ の領域において, 矩 形平板翼の空力特性を実験的に調べた。まず，アスペクト 比 3.0 から 0.5 の翼模型を用いて低レイノルズ数領域にお ける空力特性を取得し, アスペクト比の影響を明らかにし た. 次に, 実験と解析結果の比較から, 失速特性, 揚力傾 斜や風圧中心位置などに対するアスペクト比の影響の大き さとその原因について考察を行った。

\section{2. 実験装置および実験方法}

本研究で用いた風試模型は, 翼平面形が矩形の平板翼で ある。風試模型のアスペクト比は $3.0,2.0,1.5,1.0$ およ び 0.5 とした. 風試模型の翼型は厚さ $t=3 \mathrm{~mm}$, 翼弦長 $c=90 \mathrm{~mm}$ の対称翼型であり, 前縁は半径 $1.5 \mathrm{~mm}$ の半円 形状に加工している. また, 翼の後縁と翼端は翼面に対して $90^{\circ}$ となるように加工した. アスペクト比 1.0 については 翼厚比の影響を観察するために, 翼弦長 $60 \mathrm{~mm}$ と $45 \mathrm{~mm}$, 翼厚比 0.050 および 0.067 の風試模型も用いた.

風試模型に働く空気力は, 三分力天秤を用いて測定を行っ た. 本研究で用いた天科の概要を第 1 図に示す。模型を支 える支柱は片持ち梁になっている. 三分力天秤では, 模型 に負荷される法線力, 接線力およびピッチングモーメント をこの支柱によって測定ユニットに伝え，測定ユニット内 の複数のロードセルによって測定を行っている. 風試模型 


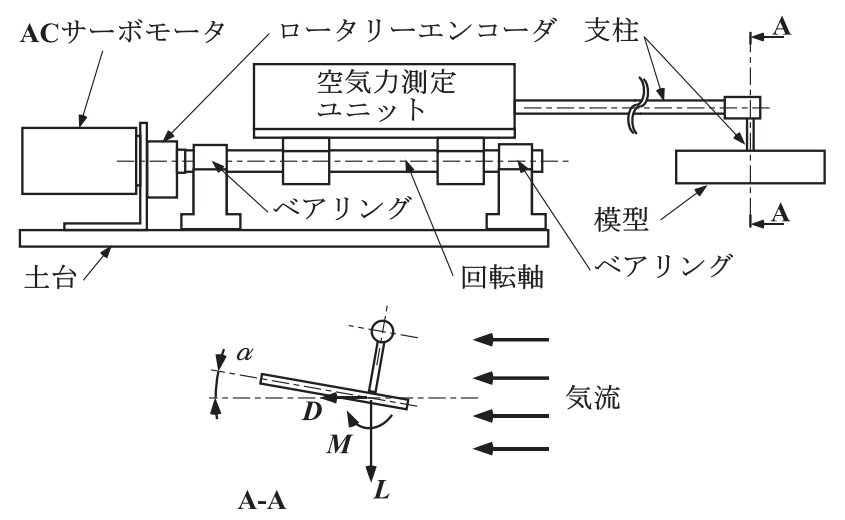

第 1 図 風洞天秤の概要

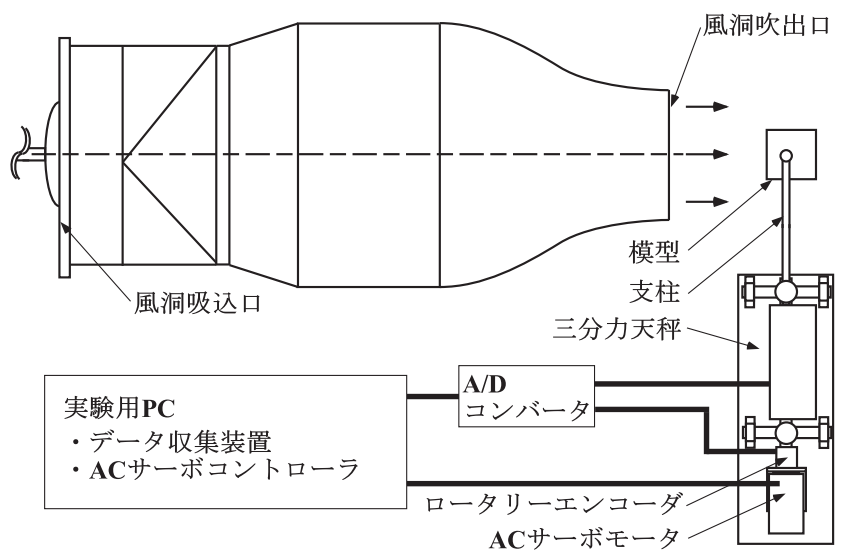

第 2 図＼cjkstart風洞と測定システムの概略図（上面図）

は翼下面側, $1 / 4$ 翼弦長位置で天秤に取り付けられる, 風試 模型の揚力係数 $C_{L}$, 抵抗係数 $C_{D}$ 抢よびピッチングモー メント係数 $C_{M}$ は, 天秤の測定結果から得られる法線力 などから求められる。 ここでピッチングモーメント係数は, 風試模型の $1 / 4$ 翼弦長位置で評価を行った. 風試模型の迎

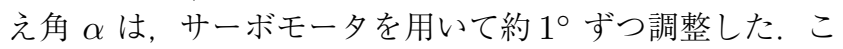
の角度の測定には, サーボモータと同じ回転軸に設置した ロータリーエンコーダを用いた，迎え角と空気力の測定は 5 秒間行い，500 点の実験デー夕を取得した。測定を行う 迎え角は, 模型に働く空気力が天秤の定格容量に収まるよ うに, $-10^{\circ}$ から $50^{\circ}$ の範囲で実験ごとに調整を行った。

風洞試験は, 防衛大学校に設置されている吹放式風洞で 行った，風洞と測定系の概略図を第 2 図に示す。この風洞の 縮流筒絞り比は 9 , 吹出口の大きさは $600 \times 600 \mathrm{~mm}^{2}$ の正 方形である。模型はこの吹出口から $350 \mathrm{~mm}$ 下流側に設置 した．実験時のレイノルズ数は $7.6 \times 10^{4}$ および $5.2 \times 10^{4}$ とした。ここでレイノルズ数の代表長は翼弦長としている. 気流の動圧は風洞吹出口に設置したピトー静圧管とゲッチ ンゲン型マノメータを用いて測定した。

風試模型は実験開始時に, 測定を行う最小の迎え角に調 整される. 空気力と迎え角の測定は気流静定後に, 迎え角

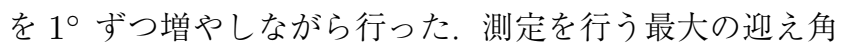

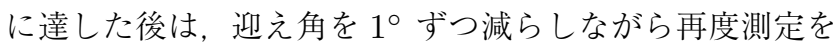
行った，実験は各模型について複数回行い，平均処理をし
て測定結果の評価を行った。また，風試模型を取り外した 状態で測定を行い，支柱抵抗の影響を考慮した。なお，本 研究の結果に対して, 支柱干渉抵抗の影響は十分無視でき るほどに小さい，測定した実験結果には風洞境界の修正 ${ }^{11}$ を行って，気流境界の影響を考慮した。また，風試模型の 迎え角には気流上向き角 ${ }^{11)}$ や風洞境界修正の他に, 模型と 天秤回転軸との取り付け角度差も考慮した。

実験結果の空力係数や迎え角について，信頼水準を $95 \%$ と して不確かさ解析を行った ${ }^{12)}$ 。迎え角の不確かさは $\pm 0.5^{\circ}$ 程度であった，本研究の実験では，空力倸数の不確かさは レイノルズ数が小さいほど大きい，迎え角がある程度大き い場合, レイノルズ数 $7.6 \times 10^{4}$ の条件に扔ける揚力倸数揖 よび抵抗係数の不確かさは $5 \%$ 以下, ピッチングモーメン 卜係数の不確かさは $6 \%$ から $10 \%$ 程度であった。また，レ イノルズ数 $5.2 \times 10^{4}$ の条件に扔ける不確かさは, 揚力係 数㧍よび抵抗倸数が $7 \%$ 以下, ピッチングモーメント係数 は少し大きく $15 \%$ 程度と見積もられた。

\section{3. 解 析 方 法}

本研究では実験で得られた揚力係数や抵抗係数について, Lamarの方法を用いて解析と考察を行った. Lamar ${ }^{13)}$ は 低アスペクト比翼の空気力を, ポテンシャル理論から求め られるポテンシャル成分と前縁や翼端で形成される渦によ る渦揚力成分にわけて考元, 解析する方法を提案している. Lamarによると，翼の揚力係数は次の式で与えられる.

$$
C_{L}=K_{\mathrm{p}} \sin \alpha \cos ^{2} \alpha+K_{\mathrm{v}} \cos \alpha \sin ^{2} \alpha
$$

また，抵抗倸数は次の式で与えられる.

$$
C_{D}=C_{D 0}+K_{\mathrm{p}} \sin ^{2} \alpha \cos \alpha+K_{\mathrm{v}} \sin ^{3} \alpha
$$

ここで $C_{D 0}$ は最小抵抗係数であり， $K_{\mathrm{p}}$ 拈よび $K_{\mathrm{v}}$ は翼 の形状やアスペクト比に依存する係数である. Lamarによ ると，非圧縮性流れに打ける $K_{\mathrm{v}}$ は $\pi$ の $10 \%$ 以内になる とされている，本研究では後に述べるように， $K_{\mathrm{p}}$ および $K_{\mathrm{v}}$ は実験結果から重回帰分析によって推定を行った。ま た，次式を用いて実験で得られた抵抗係数を近似し，抵抗 係数に対するアスペクト比の影響を考察した。

$$
C_{D}=C_{D 0}+K C_{L}^{2}
$$

Prandtl の揚力線理論によれば，アスペクト比による揚 力傾斜の変化は次の式で与えられる ${ }^{14)}$.

$$
\frac{\mathrm{d} C_{L}}{\mathrm{~d} \alpha}=\frac{a_{0}}{1+\left(a_{0} / \pi A R\right)(1+\tau)}
$$

ここで $\tau$ は翼平面形などに依存する係数であり， $a_{0}$ は二 次元翼型の揚力傾斜である. 本研究では $a_{0}=2 \pi$ として実 験值との比較を行った。 また, Hoerner ら ${ }^{3)}$ は比較的レイ ノルズ数の高い領域における実験值をもとに, 矩形翼の揚 力傾斜について次の近似式を与えている.

$$
\frac{\mathrm{d} C_{L}}{\mathrm{~d} \alpha}=\left(10+8 / A R^{2}+20 / A R\right)^{-1}\left(\frac{360}{2 \pi}\right)
$$


実験結果から揚力傾斜を評価する場合，例えば Sunada ら 7) P Pelletier ら ${ }^{9)}$ は, 小さな迎え角の範囲で揚力係数を 線形近似し，その傾きとして揚力傾斜を求めている。 しか し，この方法では小さな迎え角で非線形性が強い翼の場合， 近似に用いる迎え角の範囲によって揚力傾斜が変化してし まう。そのため Mueller ら ${ }^{1)}$ が述べているように，低アス ペクト比翼では揚力傾斜の定義や評価が困難になる。 そこ で本研究では, Lamarの方法を利用して揚力傾斜を評価す る方法を提案し, 実験との比較を行う。(1) 式を迎え角で微 分すると, 迎え角 $0^{\circ}$ の揚力傾斜として次の式が得られる.

$$
\left.\frac{\mathrm{d} C_{L}}{\mathrm{~d} \alpha}\right|_{\alpha=0}=K_{\mathrm{p}}
$$

したがって, 実験值より推定したパラメータ $K_{\mathrm{p}}$ の值は, 迎え角 $0^{\circ}$ における揚力傾斜を表している.

Torres ら10) はピッチングモーメントと法線力から風圧 中心の位置を求めている. 本研究でも Torres らの方法を用 いて，翼の風圧中心位置について解析と考察を行った。

\section{4. 結 果 と考 察}

4.1 実験結果 第 3 図から第 7 図に, 風洞実験で得ら れたアスペクト比 $3.0,2.0,1.5,1.0$ および 0.5 の矩形翼 空力特性を示す. 風試模型の翼厚比は 0.033 である. アス ペクト比が 1.5 以下については，レイノルズ数 $7.6 \times 10^{4}$ の条件における結果を示している。また，アスペクト比 2.0 以上の場合，レイノルズ数が大きい条件では測定可能な範 囲が制限されたため, レイノルズ数 $5.2 \times 10^{4}$ の実験結果 を示している.

アスペクト比が 3.0 の場合, 翼の空力特性は小さな迎え 角で線形的であることが第 3 図よりわかる. 揚力係数は迎 え角 $8^{\circ}$ 付近まで迎え角に比例している。ささらに大きな迎 え角では揚力係数の増加が緩やかになり, 迎え角が $18^{\circ}$ 超えると揚力係数はほぼ一定となっている. 抵抗係数は迎 え角の増加に対して単調に増加している. ピッチングモー メント係数は迎え角が $0^{\circ}$ から $5^{\circ}$ の範囲でわずかに増加 し，迎え角が 5 をを超えると減少している，また，大きな 迎え角でのピッチングモーメント係数は, 揚力係数と同様

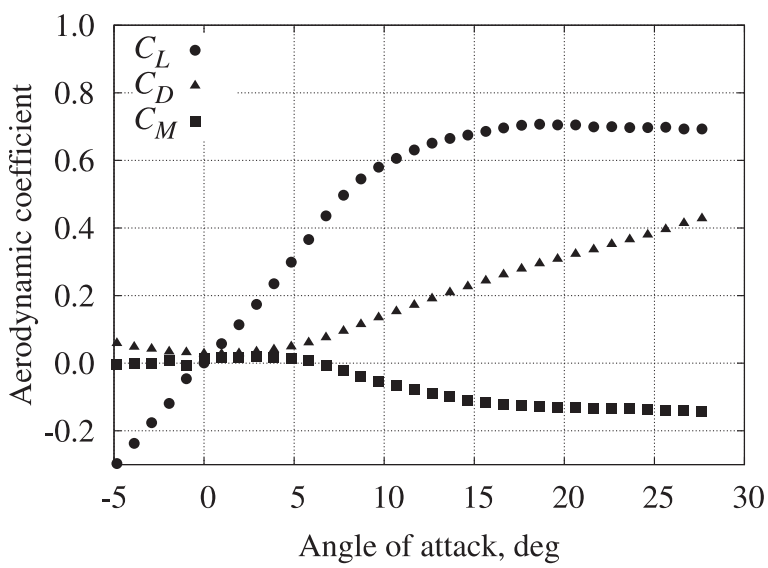

第 3 図 矩形翼の空力特性 $\left(A R=3.0, R e=5.2 \times 10^{4}\right)$
にほぼ一定值を示している。このような空力係数の迎え角 に対する変化は, アスペクト比がより大きい平板翼の実験 結果 $\left.{ }^{2,6}, 7\right)$ や二次元翼型の測定結果 ${ }^{8)}$ と定性的に一致してい る.このため, アスペクト比 3.0 の矩形翼に対するアスペク 卜比の影響は小さく, 空力特性は翼型特性に依存している と考えられる。また，第 3 図からは，レイノルズ数 $10^{4}$ の 領域における翼厚比 0.033 の平板翼は, レイノルズ数の低 さに起因する揚力特性の非線形性を示さないことがわかる.

アスペクト比が 2.0 の場合，第 4 図に示すように迎え角 $10^{\circ}$ 付近まで揚力傾斜はほぼ一定である。迎え角が $10^{\circ}$ を 超えると揚力係数の増加は緩やかになり, 最大揚力係数は 迎え角 $19^{\circ}$ 付近で得られている.さらに大きな迎え角では, 揚力係数はアスペクト比 3.0 の場合と同じ值に減少してい る. 抵抗係数は迎え角に対して増加を続けるが, 最大揚力 係数付近の迎え角で，増加率が緩やかになっている，ピッ チングモーメント係数はアスペクト比 3.0 の場合と同じよ うに迎え角 $5^{\circ}$ 付近から減少を始め, 揚力係数が最大值に 達すると，わずかに増加した後にほぼ一定值を示した。こ のように, アスペクト比が 2.0 になると, 最大揚力係数が 得られる迎え角付近で特性に変化が観察された。

第 5 図に示したアスペクト比が 1.5 の場合，最大揚力係 数は迎え角 $22^{\circ}$ 付近で得られており，この迎え角まで揚力

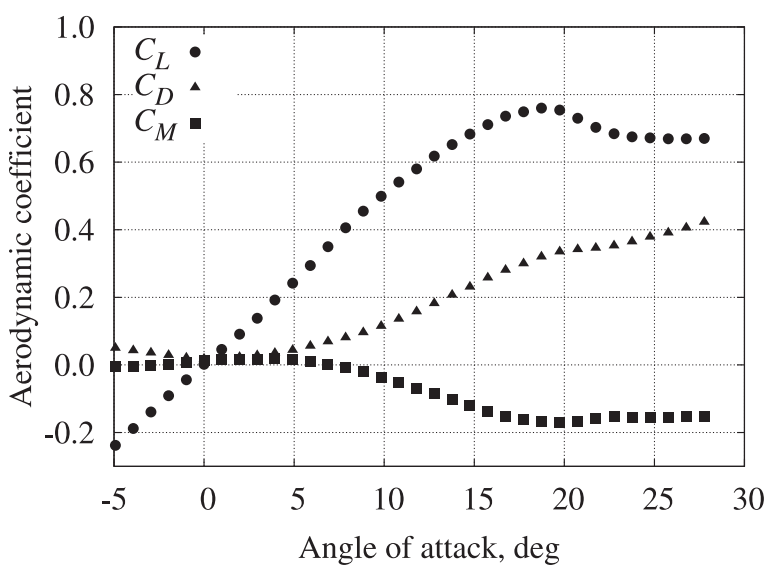

第 4 図 矩形翼の空力特性 $\left(A R=2.0, R e=5.2 \times 10^{4}\right)$

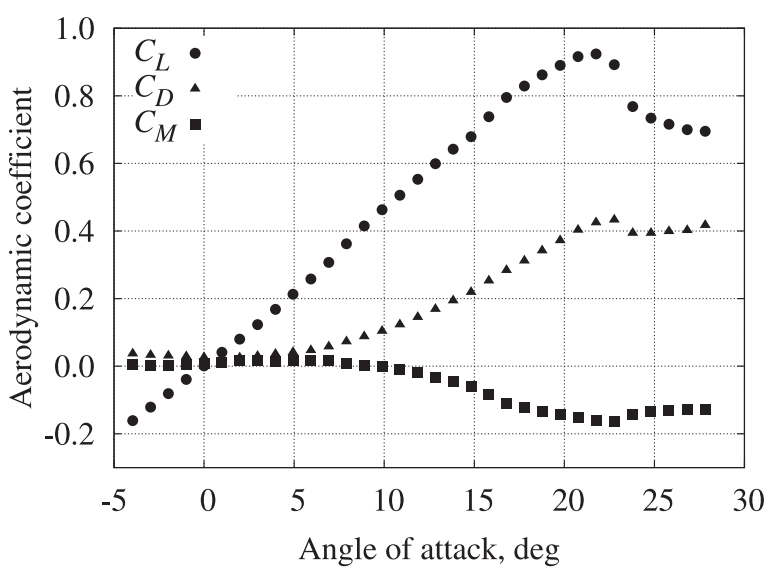

第 5 図 矩形翼の空力特性 $\left(A R=1.5, R e=7.6 \times 10^{4}\right)$ 


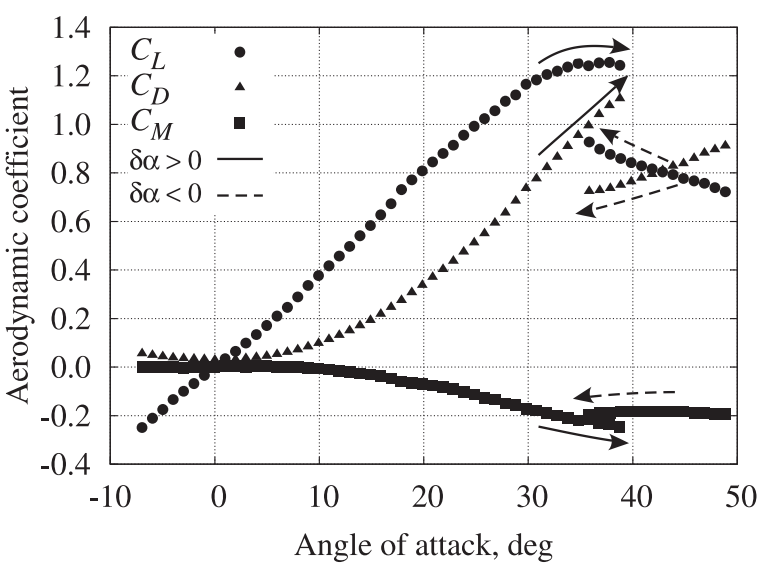

第 6 図 矩形翼の空力特性 $\left(A R=1.0, R e=7.6 \times 10^{4}\right)$

は増加を続けている，ただし，揚力傾斜は迎え角 $7^{\circ}$ 付近 で変化している. 最大揚力係数到達後の各空力係数の変化 は，アスペクト比 2.0 の場合と定性的には変わらない.

アスペクト比が 1.0 の場合, 第 6 図に示すように揚力係 数は迎え角 $20^{\circ}$ 付近まで増加を続ける。 また, 迎え角 $20^{\circ}$ 以降では揚力傾斜が少し減少している。ささらに迎え角が大 きくなると, 翼は迎え角 $39^{\circ}$ 付近で失速し, 急激な揚力係 数の減少が観察された。一方, 迎え角を減らしながら測定 を行った結果からは, 流れの再付着が迎え角 $35^{\circ}$ で発生し ていることがわかる.このようにアスペクト比 1.0 の矩形 翼では，失速角付近でヒステリシスが発生している，失速 時のヒステリシスは翼厚比を変えた場合も，アスペクト比 1.0 の風試模型で観察された。抵抗係数は失速時に一度大 きく減少し, さらに大きな迎え角では再度緩やかに増加し ている，ピッチングモーメント係数も失速前後で不連続な 変化を示し，失速後はほぼ一定になっている。また，この アスペクト比の矩形翼では，ピッチングモーメント係数の 減少は迎え角 $10^{\circ}$ 付近から発生している。

アスペクト比が 0.5 の場合は第 7 図に示すように，小さ な迎え角でも揚力傾斜が迎え角に強く依存している。 また， このアスペクト比の翼の失速特性はアスペクト比 1.0 の翼 と比べて穏やかであり，失速時のヒステリシスも観察され ない．抵抗係数は迎え角の増加に対して増加を続けている. 失速後の抵抗の増加は少し緩やかになるが，アスペクト比 1.0 の場合のような, 失速時の抵抗係数の減少は生じてい ない. ピッチングモーメント係数の迎え角に対する変化は, 低い迎え角では定性的にアスペクト比 1.0 と一致している. また, アスペクト比が 0.5 の場合は, 失速後もピッチング モーメント係数が減少を続けていることが第 7 図からわか る.これらの特性の変化は, 流れの構造がアスペクト比 1.0 以上の場合と大きく異なることを示唆している.

第 8 図に，最大揚力係数のアスペクト比による変化を示 す.レイノルズ数が大きい場合, 最大揚力係数はわずかに 大きくなることが第 8 図からわかる。これはレイノルズ数 が大きい方が流れの剝離が遅れることが原因と考えられる。 また，本研究で用いた矩形翼では，アスペクト比 1.0 と 1.5

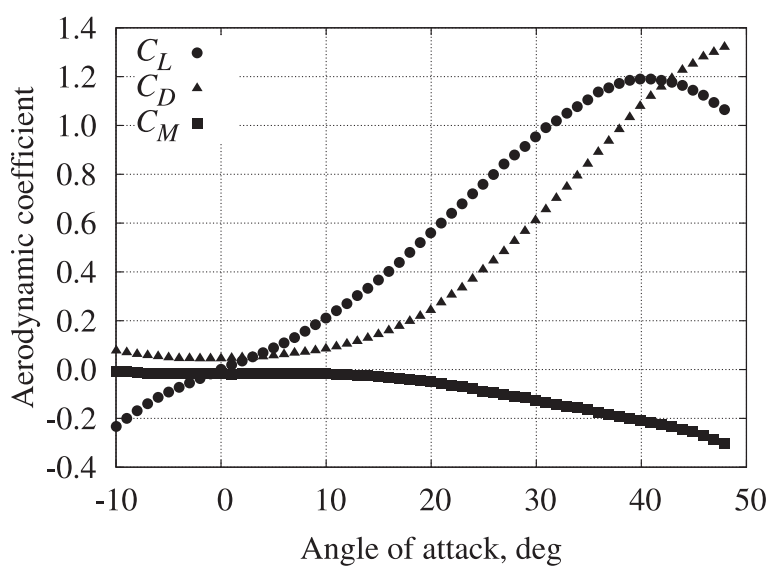

第 7 図 矩形翼の空力特性 $\left(A R=0.5, R e=7.6 \times 10^{4}\right)$

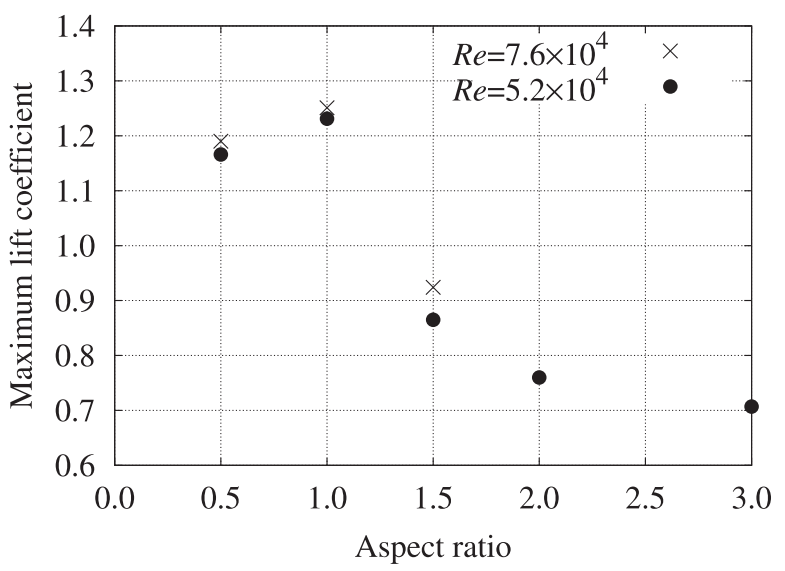

第 8 図 最大揚力係数の比較

の間で最大揚力係数が大きく増加することがわかる.

ここまでに述べたようなアスペクト比が空力特性に及ぼ す影響の大きさや傾向は, Torresら ${ }^{10)}$ が翼厚比 0.0196 の 矩形翼について行ったレイノルズ数 $10^{5}$ の領域に扔ける実 験結果と, ヒステリシスの発生を除いてほぼ一致した。し たがって, レイノルズ数 $10^{4}$ から $10^{5}$ の領域における翼空 力特性に対してアスペクト比が及ぼす影響は，レイノルズ 数に依存せず同じ程度であることが明らかになった。

4.2 解析結果との比較 本研究では, 先に示した Lamar の方法を用いた解析を行い，実験との比較と考察を行った. Lamar が拡張したデル夕翼に関する Polhamus の理論 ${ }^{15)}$ では，翼が十分に薄く前縁が鋭いことを想定している，そこ で本研究ではまず, 翼厚比がパラメー夕 $K_{\mathrm{p}}$ および $K_{\mathrm{v}}$ に 及ぼす影響を重回帰分析を用いて調べた。ここで，Lamar の方法は流れや渦の剝離を想定していない，そのため回帰 分析に用いた実験值の範囲は，アスペクト比が 1.0 以下の 場合は迎え角 $20^{\circ}$ までとし，アスペクト比が 1.5 以上の場 合は，揚力傾斜が減少するまでの迎え角とした，第 9 図に アスペクト比が 1.0 の風試模型について, パラメータ $K_{\mathrm{p}}$ および $K_{\mathrm{v}}$ の推定結果を示す. 第 9 図には Torres ら ${ }^{10)} に$ よるアスペクト比 1.0 の矩形翼の推定值も，比較のために 


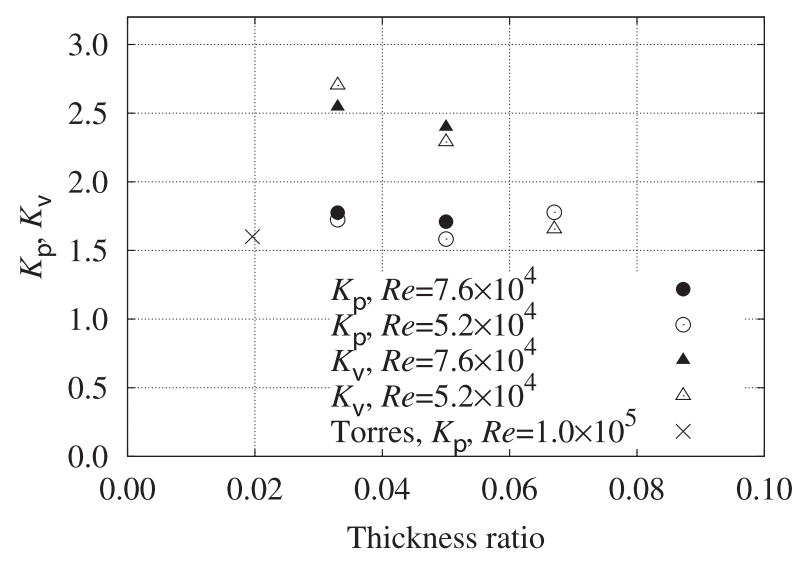

第9図 $K_{\mathrm{p}}$ および $K_{\mathrm{v}}$ に対する翼厚比の影響10)

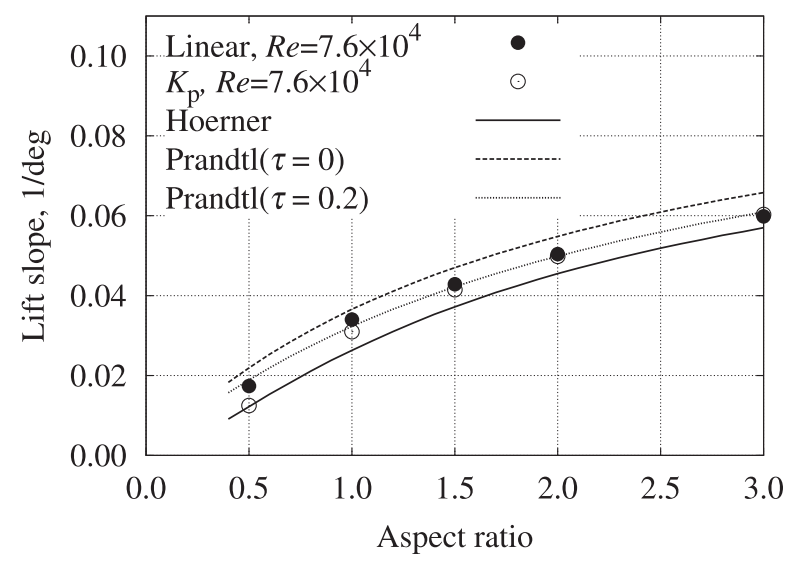

第 10 図 揚力傾斜

示している. なお, Torresらは $K_{\mathrm{v}}=\pi$ と近似して解析を 行っている. 第 9 図から $K_{\mathrm{p}}$ は翼厚比に依存せず，ほぼ一 定であることがわかる．また，本研究に拈ける $K_{\mathrm{p}}$ の推定 結果は, Torresらの推定值とほぼ一致している。一方, 渦 揚力の影響を表すパラメータ $K_{\mathrm{v}}$ は, 翼厚比が大きいほど 小さくなることが第 9 図からわかる。これは, 翼厚比が小 さいほど翼端渦が強くなるためである。本研究の結果から は翼厚比が 0.030 程度を超えると， $K_{\mathrm{v}}$ の翼厚比に対する 依存性を考慮する必要があることがわかる。

第 10 図に迎え角 $0^{\circ}$ に抒ける揚力傾斜のアスペクト比に よる変化を示す，第 10 図には迎え角 $0^{\circ}$ から $5^{\circ}$ の範囲で揚 力係数と迎え角の関係を線形近似して求めた值と, (6) 式か ら求めた值を比較して示している. 先に述べたようにアス ペクト比が大きい場合は, 揚力傾斜が減少する迎え角まで, 揚力は線形的である。第 10 図では，アスペクト比が 2.0 以 上の場合に線形近似によって求めた揚力傾斜と, (6) 式から 求めた揚力傾斜はよく一致している。 このことから Lamar の方法を利用した揚力傾斜の評価は, 線形的な揚力特性を 有する翼に対して有効であることがわかる。一方，アスペ クト比が小さい場合には評価方法によって揚力傾斜に差が 生じている，先に述べたように，アスペクト比が小さい翼 ほど揚力の非線形性が強い, そのため, 線形近似によって

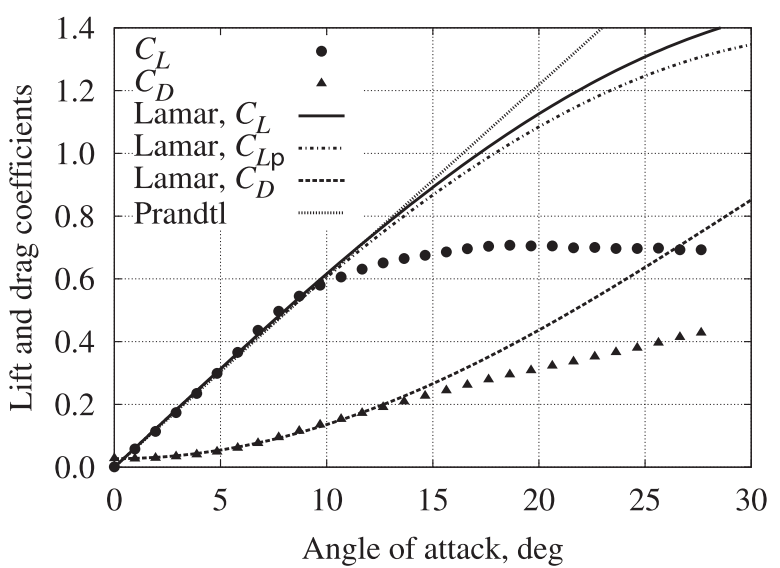

第 11 図 Lamar の方法との比較 $\left(A R=3.0, R e=5.2 \times 10^{4}\right)$

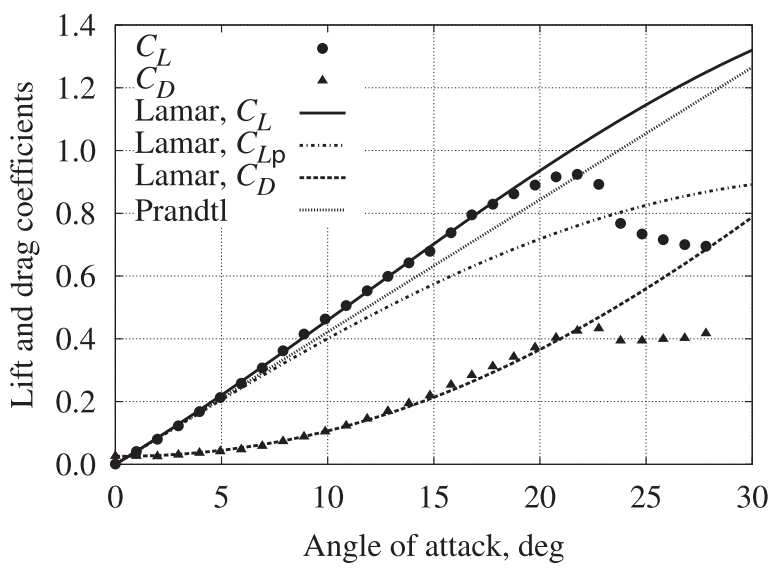

第 12 図 Lamar の方法との比較 $\left(A R=1.5, R e=7.6 \times 10^{4}\right)$

評価された揚力傾斜は，近似に用いる迎え角の範囲に強く 依存する。一方, 本研究で提案した方法では, 揚力傾斜が減 少するまでのより広い迎え角の範囲を近似に利用する。こ のため近似範囲に対する揚力傾斜の依存性が小さく, より 適切に揚力傾斜を評価できると考えられる。第 10 図から は, レイノルズ数 $10^{4}$ の領域に扔ける矩形平板翼の揚力傾 斜は, アスペクト比が小さい場合, 高レイノルズ数流れの 揚力傾斜を近似する Hoerner の式に近づくことがわかる. また，アスペクト比が大きい場合は， $\tau$ を 0.2 とした揚力 線理論の式が実験值をよく近似していることもわかる.

第 11 図加第 13 図に, 実験結果と Lamar の方法から求 められた解析結果を比較して示す，それぞれの図には Lamar の方法から求められる揚力倸数のポテンシャル成分 $C_{L \mathrm{p}}$ と, $\tau$ を 0.2 として Prandtl の揚力線理論から求めた揚力係数 を比較のために示している.アスペクト比が 3.0 の場合（第 11 図), Lamar の方法による解析から, 迎元角 $10^{\circ}$ 以下 の揚力はほぼポテンシャル成分であることがわかる。また， この解析結果や実験值は, 揚力線理論から求められた揚力 係数とも, 迎え角が $10^{\circ}$ 以下でよく一致している。抵抗係 数についても, Lamarの方法は失速が始まるまでの実験結 果をよく模擬している. Lamarの方法による全揚力とポテ ンシャル揚力の差は, 翼端渦の影響の大きさを表している. 


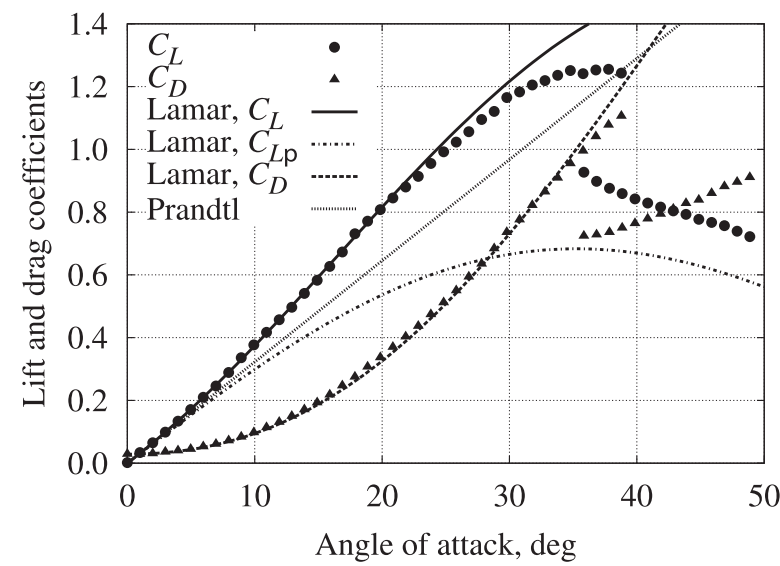

第 13 図 Lamar の方法との比較 $\left(A R=1.0, R e=7.6 \times 10^{4}\right)$

したがってアスペクト比 3.0 の場合，渦揚力による影響は 無視できるほど小さいことがわかる.

アスペクト比が 1.5 の場合（第 12 図），Lamarの方法は 最大揚力係数が得られる迎え角近くまで, 実験結果をよく 模擬できていることがわかる．また，このアスペクト比で は迎え角 $7^{\circ}$ 付近から, 揚力倸数が揚力線理論から求めら れる值よりも大きくなる，第 12 図からわかるように，迎え 角が大きいほど渦揚力の全体に対する割合は増加する。こ の渦揚力が揚力傾斜を大きくしていると考えられる，迎え 角が小さい場合は渦揚力の寄与も小さいため, 揚力傾斜の 変化も小さい，また，翼端渦による空気力は，渦の負圧領 域によって生じている．失速後の揚力と抵抗の減少は，こ の翼端渦の崩壊に起因すると考えられる.

アスペクト比が 1.0 の場合（第 13 図），Lamar の方法に よって推定される揚力係数は迎え角 $20^{\circ}$ 付近まで実験結果 とよく一致している．揚力係数は迎え角が $5^{\circ}$ 付近から揚 力線理論による値よりも大きい.これは先と同様に渦揚力 の影響と考えられる. また, 失速後の揚力係数や抵抗係数 の減少は, アスペクト比 1.5 の場合と同じように, 失速に よって渦による空気力の寄与が失われたためと考えられる. したがって, 失速時のヒステリシスの発生も, 翼端渦の挙 動と関係していると考えられる。

第 14 図に, レイノルズ数 $5.2 \times 10^{4}$ の条件で最大揚力係 数が得られたときの迎え角 $\alpha_{\max }$ と $\alpha_{\mathrm{vor}}$ 拈よび $\alpha_{\text {stall }}$ を アスペクト比ごとに比較して示す。ここで $\alpha_{\mathrm{vor}}$ は渦揚力の 影響が現れ始める迎え角の目安として, 渦揚力が揚力全体 の $10 \%$ 超過した角度と定義する。 また, 本研究では失速 角 $\alpha_{\text {stall }}$ を, Lamar の式から得られる解析解と実験值との 差が $10 \%$ を超えた角度として定義する．アスペクト比 3.0 では，有意な差で $\alpha_{\max }$ を定義できなかった，しかしその 角度は第 3 図から，18以上であることがわかる，そのた め先に述べた最大揚力係数と同様に， $\alpha_{\max }$ もアスペクト 比 1.0 と 1.5 の間で大きく変化することが, 第 14 図からわ かる，また，失速角はアスペクト比が小さいほど大きい．

アスペクト比 3.0 の場合, 揚力に対する渦揚力の影響は 非常に小さく， $\alpha_{\mathrm{vor}}$ も定義できない。 アスペクト比が 2.0

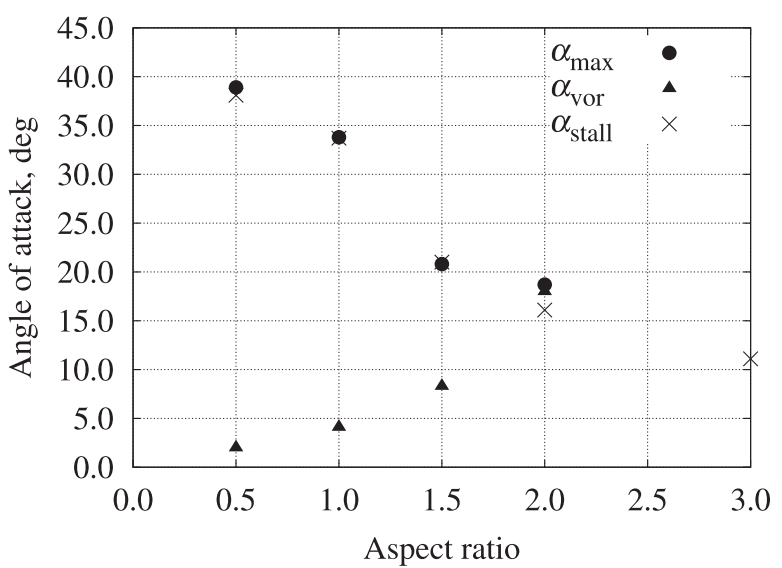

第 14 図 最大揚力時の迎え角, 失速角と渦揚力の影響

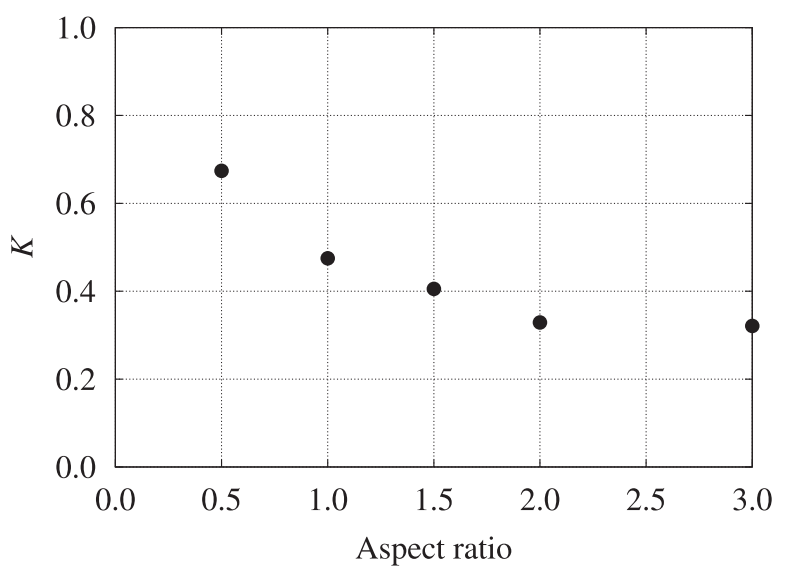

第 15 図 $K$ に対するアスペクト比の影響 $\left(R e=7.6 \times 10^{4}\right)$

付近になると，失速角と $\alpha_{\mathrm{vor}}$ が近づいている，そのため 先に第 4 図で示したように，渦揚力の影響はまず失速特性 に現れると考えられる．さらにアスペクト比が小さくなる と $\alpha_{\mathrm{vor}}$ も小さくなるため, 渦揚力の影響は失速前の低い 迎え角から現れ始める。このためアスペクト比が 1.5 以下 の翼では，失速特性だけではなく揚力傾斜も渦の影響を受 け，揚力特性が非線形性を示すと考えられる。また，アス ペクト比 1.0 以下での最大揚力係数や失速角の大きな増加 は，洞揚力の寄与の大きさに起因すると考えられる。この ように第 14 図からは，アスペクト比が小さいほど渦揚力の 影響が現れる迎え角が小さくなることが明らかになった。

第 15 図に (3) 式の係数 $K$ とアスペクト比の関係を示す. 揚力による抵抗の増加はアスペクト比が小さいほど大きい ことがわかる．この傾向は Torres ら ${ }^{10)}$ の報告ともよく一 致した。 また，係数 $K$ に対するレイノルズ数依存性は本 研究の結果からは観察されなかった。な抢，アスペクト比 による $C_{D 0}$ の変化は不確かさの範囲内であった

第 16 図に風圧中心位置の推定結果を示す。ここで $h_{\mathrm{cp}}$ は翼弦長で無次元化した前縁から風圧中心までの距離であ る.アスペクト比 0.5 から 2.0 の条件における風圧中心の推 定にはレイノルズ数 $7.6 \times 10^{4}$ の実験結果を用いた。 また, 


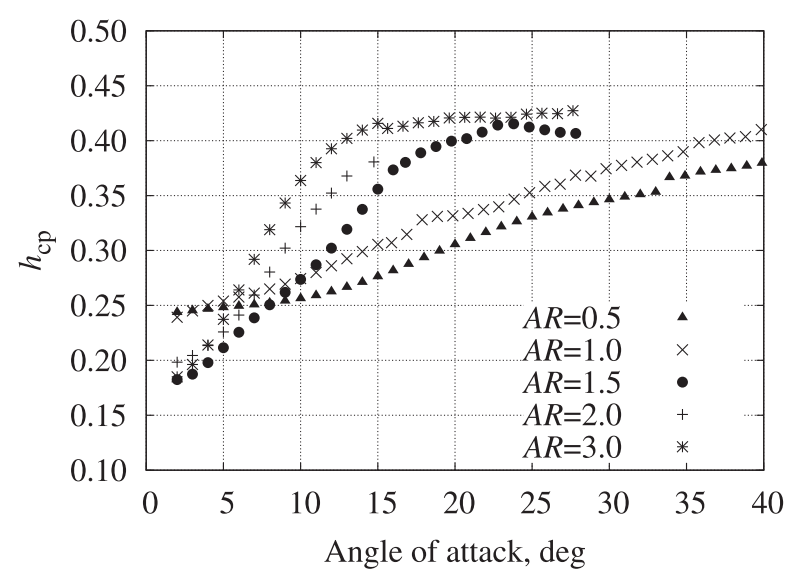

第 16 図 風圧中心位置の変化

アスペクト比が 3.0 の場合は, レイノルズ数 $5.2 \times 10^{4}$ の 実験結果を用いた，第 16 図よりアスペクト比が 1.5 以上の 場合, 小さな迎え角での風圧中心は $1 / 4$ 翼弦長より前縁に 近い位置にあることがわかる，迎え角が大きくなると，風 圧中心は後縁側へ移動している。一方，アスペクト比が 1.0 以下で迎え角が小さい場合の風圧中心は $1 / 4$ 翼弦長付近で ある。また, 迎え角に対する風圧中心の移動は, アスペク 卜比が小さいほど緩やかである。これらのことから，レイ ノルズ数 $10^{4}$ の領域における平板翼の風圧中心は, 迎え角

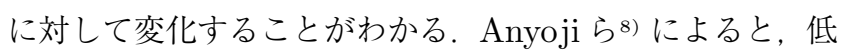
レイノルズ数流れにおける平板翼型には迎え角が小さい場 合でも, 前縁付近に層流剥離泡が形成されている。アスペ クト比が比較的大きい場合, 風圧中心やピッチングモーメ ント係数の迎え角依存性は, この層流剥離泡の挙動に影響 を受けていると考えられる。また, 先に第 14 図で述べたよ うに，アスペクト比が小さいほど翼端渦の影響が大きくな る。このため低アスペクト比の場合, 風圧中心の迎え角依 存性が第 16 図のように変化すると考えられる.

\section{5. 結 論}

本研究では, レイノルズ数 $10^{4}$ 程度の低レイノルズ数流 れにおいて，アスペクト比が矩形平板翼の特性に及ぼす影 響を実験的に調べた。本研究から得られた知見は, 次のよ うにまとめられる.

1）矩形平板翼の失速特性に対するアスペクト比の影響 は, アスペクト比が 2.0 以下で観察された。 また, 揚力傾斜 に対するアスペクト比の影響は, アスペクト比 1.5 以下で 現れた。さらにアスペクト比が 1.0 以下になると，最大揚 力係数や最大揚力係数が得られる迎え角が大きく増加した.

2）アスペクト比 1.0 の場合, 本研究で扱った翼厚比 0.033
から 0.067 の矩形平板翼では，失速時にヒステリシスが発 生する。

3）渦揚力の影響は, 翼厚比が小さいほど大きい.

4）翼の揚力傾斜について, Lamarの方法を用いた評価 方法を提案した。この方法によって揚力係数が非線形な翼 についても，適切な揚力傾斜の評価が可能になった.

5）アスペクト比が空力特性に及ぼす影響は，アスペクト 比が小さいほど小さな迎え角から現れる。これは翼端渦に よる渦揚力の影響であると考えられる.

6）低レイノルズ数流れにおける平板翼の風圧中心は，迎 え角に対して変化することを示した。

\section{参 考 文 献}

1) Mueller, T. J., Kellogg, J. C., Ifju, P. G. and Shkarayev, S. V.: Introduction to the Design of Fixed-Wing Micro Air Vehicles Including Three Case Studies, AIAA, Reston, 2006, pp. 1-107.

2) Schmitz, F. W.: Aerodynamics of the Model Airplane. Part 1. Airfoil Measurements, RSIC-721, 1967.

3) Hoerner, S. F. and Borst, H. V.: Fluid-Dynamic Lift, 2nd ed., Published by Hoerner, L. A., 1985, pp. 2-17, 17-3.

4) Mueller, T. J. and Batill, S. M.: Experimental Studies of Separation on a Two-Dimensional Airfoil at Low Reynolds Numbers, AIAA J., 20 (1982), pp. 457-463.

5) 大竹智久, 中江雄亮, 本橋龍郎：低 $R e$ 数領域での NACA0012 翼の非線形空力特性, 日本航空宇宙学会論文集, 55 (2007), pp. 439-445.

6) Okamoto, M., Yasuda, K. and Azuma, A.: Aerodynamic Characteristics of the Wings and Body of a Dragonfly, J. Exp. Biol., 199 (1996), pp. 281-294.

7) Sunada, S., Yasuda, T., Yasuda, K. and Kawachi, K.: Comparison of Wing Characteristics at an Ultralow Reynolds Number, J. Aircraft, 39 (2002), pp. 331-338.

8) Anyoji, M., Nose, K., Ida, S., Numata, D., Nagai, H. and Asai, K.: Low Reynolds Number Airfoil Testing in a Mars Wind Tunnel, AIAA Paper 2010-4627, 2010.

9) Pelletier, A. and Mueller, T. J.: Low Reynolds Number Aerodynamics of Low-Aspect-Ratio, Thin/Flat/CamberedPlate Wings, J. Aircraft, 37 (2000), pp. 825-832.

10) Torres, G. E. and Mueller, T. J.: Low-Aspect-Ratio Wing Aerodynamics at Low Reynolds Numbers, AIAA J., 42 (2004), pp. 865-873.

11) Barlow, J. B., Rae, Jr., W. H. and Pope, A.: Low-Speed Wind Tunnel Testing, 3rd ed., John Wiley \& Sons, New York, 1999, pp. 264-288, 367-427.

12) Coleman, G. W. and Steele, W. G.: Engineering Application of Experimental Uncertainty Analysis, AIAA J., 33 (1995), pp. 1888-1896.

13) Lamar, J. E.: Extension of Leading-Edge-Suction Analogy to Wings with Separated Flow around the Side Edges at Subsonic Speeds, NASA TR R-428, 1974.

14) Anderson, Jr., J. D.: Fundamentals of Aerodynamics, 5th ed., McGraw-Hill, New York, 2011, pp. 424-463.

15) Polhamus, E. C.: Predictions of Vortex-Lift Characteristics by a Leading-Edge Suction Analogy, J. Aircraft, 8 (1971), pp. 193-199. 